Apidologie, 1984, 15 (4), 363-378

\title{
COMPARATIVE EFFECTIVENESS OF TREATMENTS USED TO CONTROL VARROA JACOBSONI OUD.
}

\author{
Stefano MARCHETTI and Renzo BARBATTINI \\ with the technical collaboration of Mauro D'AGARO \\ Istituto di Difesa delle Piante, Universita' degli Studi di Udine \\ P. le $M$. Kolbe, 4 \\ I - 33100 Udine. Italia
}

\begin{abstract}
SUMMARY
During the autumn of 1983 the efficacy of four trade products (Folbex VA, Apiakaridim, Taktic and Thymol crystals) was compared using 40 honey bee colonies. Taktic was used only once, the others four times, each at four day intervals. The trial enabled us to ascertain a lower effectiveness of Thymol crystals, while the remaining products were not significantly different. Wide differences were noted among mite response-curves for the four products; mite fall was very rapid for Taktic and Apiakaridim and slow for Thymol crystals. The most consistent results were shown by Folbex VA, the least by Thymol crystals. The use of Folbex VA and Apiakaridim caused no damage to adult bees or brood, Thymol crystals damaged brood only under certain conditions. It was not possible to assess whether the relative weakening of some colonies treated with Taktic was due to the use of amitraz, the execution of a late treatment, or both.
\end{abstract}

\section{INTRODUCTION}

The use of a range of chemical substances is at present necessary to control varroatosis in all the infested European countries. Under our conditions we have observed no reduction in the reproduction of the parasite due to natural factors such as the host/parasite relationship, temperature, etc. (RITTER and DE JoNG, 1984). Several authors (Grobov, 1977 ; RutTnER et al., 1980 a, 1980 b ; RitTer, 1981 ; CL̈̈̈ERR, 1983 ; RitTER et al., 1983 b) have claimed that repeated drone brood removal is alone insufficient to keep the number of Varroa mites low over a long time. Therefore, biotechnical control must be at present combined

Trials carried out with the financial contribution of the EC Commission and of the Ministero dell'Agricoltura e Foreste (contract no. 005245 : short term research program against varroatosis). 
with chemotherapy, including the use of «natural " substances (POLTEV, 1978 ; Smirnov, 1978 ; GnÄdinger, 1979 ; Mel'nik, 1979 ; Ruttner and Koeniger, 1979).

Chemical treatments have enabled beekeepers to prevent great losses of colonies and to restore heavily damaged apiaries to their former condition. A number of substances have proved successful against the mite, but often the trials have been conducted using different methods in the evaluation of their efficacy (Alpatov et al., 1977 ; Chamoux, 1977 ; Rakhmatulin, 1978 a, 1978 b ; Maul et al., 1980 ; De Jong et al., 1982 ; Ritter and Perschil, 1983 ; Santas, 1983).

A uniform technique for controlling Varroa within the European Community has been suggested (CAvalloro, 1983), but this hope has not yet been realized. In order to evaluate some of the chemical treatments in use, the Istituto di Difesa delle Piante of the University of Udine has conducted controlled trials during the autumn of 1983 . In this article we present the results of the trials, except those concerning residues which will be the subject of a later article.

\section{MATERIALS AND METHODS}

Four commercial products were compared. They are Folbex VA (bromopropylate; Ciba-Geigy), Apiakaridim (tedion + malathion; Dalmed), Taktic (amitraz; Fbc) and Thymol (crystalline : Janousek).

Observations were made in four locations of the Friulian countryside (north-east of Italy) : three of them are characterized by the same temperate climate, one is definitely milder. Instead of testing the effectiveness of all the products in every location, we used each apiary for testing a single product to simplify the work involved.

We used 40 honey bee colonies, equally subdivided among the products tested. Bee lines were derived from free-flying crosses and re-crosses between Apis mellifera carnica and A. m. ligustica. Dadant-Blatt type hives with ten combs were used for tests of Folbex VA, Apiakaridim and Thymol, Langstroth hives for the test of Taktic.

\section{Bromopropylate}

Folbex VA was approved by the Italian Health Ministry on 21 July 1983. Treatment with bromopropylate began on 18 October. Four fumigations were made at four day intervals. Each treatment was executed near sunset with external temperatures not below $10^{\circ} \mathrm{C}$, in closed hives without empty supers added. Just before closing the entrance an insert with $2.5 \mathrm{~mm}$ mesh over grease-proof paper with a layer of vaseline (RITTER et al., 1983 a) was placed on the hive floor by inserting it through the hive entrance. Identical inserts were used to test the effectiveness of the other chemicals on trial.

On the occasion of the second fumigation, swift substitutions of the inserts were executed to obtain the mite response-curve to bromopropylate. 


\section{Tedion + Malathion}

The active ingredients contained in Apiakaridim make this product very similar to Danikoroper (Yuko Chem. Ind.). Both ingredients are registered in Italy but not for controlling Varroa.

The roll of corrugated paper has inside the central part of its grooves little cylindrical bodies which contain the acaricides. Each roll is sufficient to fumigate 30 colonies; since 15 were to be treated (5 were used for residue testing), the roll was divided in two with a vertical cut. To ensure as far as possible consistency of our results, $D^{r}$ Klun and his colleagues of the Zveza cebelarskih drustev za Slovenijo advised us to carry out the fumigation in a rotational way until the paper was completely burned.

Dates and number of treatments were the same as those for Folbex VA; also the mite response-curve to tedion-malathion was determined in a manner similar to that for Folbex VA.

\section{A nitraz}

Amitraz has been approved by the ltalian Health Ministry only for the control of pests in animal husbandry (cattle, pigs, sheep and go:ts), fruit-growing and horticulture.

It was ascertained in laboratory tests that amitraz exerts relatively late and poisonous effects on adult bees (ARzont and VIDANO, 1980). It is not, however, known how significant they would be in practice, after an autumn treatment with the usual low doses.

In conducting the treatment we chose a) the aerosol formulation, obtained by using the atomizer Phagogene S Microdiffuseur; b) a concentration of amitraz in the emulsion equal to $2 \mathrm{ml} / \mathrm{l}$; c) a time necessary to treat one colony of about 150 seconds and d) a temperature at the exit of the atomizer of $37^{\circ} \mathrm{C}$.

Each hive was provided with an empty super. At the start of the treatment the end of the tube from the nebulizer was inserted into the feed-hole, while the flight entrance was left fully open to ensure a good flow of the acaricite through the hive.

The present cost of the atomizer is high. Therefore, its purhcase is possible only for professional beekeepers or bekecpers associations; both could carry out the treatment on behalf of hobby beekeepers. That will be possible only if a single treatment is required. Then, the colonies should contain little or no brood. In our trial we produced this situation by treating only once and relatively late in the season (28 October).

\section{Thymol}

The Thymol crystals we used were produced via chemical synthesis. The content of thymol was nearly $99 \%$. During our visit to Vzrejni Center near Ljubljana in September 1983 we were impressed by the widespread use of this substance in the area. Usually the treatment is applica in late summer, and it is preceded by drone brood removal during the active season. Although a three year application of this control strategy has been encouraging, the results remain inconclusive.

As a result of the Jugoslavian experience with thymol, several local beckecpers have adopted its use. In Italy it maty at present be used as a matural flavoring agent in foods or drugs.

In our trial, we used Thymol erystals in the milder location. Four treatments were given at four day intervals. Rain caused a two day delay in the second treatment. The dose per colony was 15 grams. Crushed crystals were placed in a small gauze bag which was suspended between two outer combs. In some colonies not included in the trial a bag of Thymol was placed in a central position near the brood for one day. The hive cntrances were reduced to the usual winter size. The treatment was started on 12 October at $11.00 \mathrm{am}$.

In all locations we installed a thermohygrograph to monitor temperature during treatments. In order to assess the number of mites left alive after the tratments, queens were cagcd in the middle 
of the central combs. When all brood had emerged two strips of Folbex VA were used at one day intervals in each hive. From work done in West Germany, there are enough data to establish the reliability of this method. During the period when the queens were caged an insert was present on the hive floor. Since external temperatures we:e below $10^{\circ} \mathrm{C}$ (the minimum for Folbex VA use) for a considerable time, the caging period for the queens lasted longer than we had intended. As a consequence some queens died, but they were replaced soon after the control treatments.

At the end of the trial we placed in the hives inserts to collect winter debris. They were taken out on 18 March 1984, the date another strip of Folbex VA was used by the veterinarians of the U.S.S.L. no, 2 in collaboration with the Beekeepers' Association of the province of Gorizia. Unfortunately, because the apiary in which Thymol was used is located outside the jurisdiction of both the above-mentioned institutions, the results of these further trials are not available.

Finally, in the spring and summer of 1984 we assessed the condition of the colonies used to collect honey and wax samples for residue analysis to compare them with those in which the trial for effectiveness of the products had been carried out. Other careful examinations were made during winter to determine the presence or the absence of brood and young bees.

\section{RESULTS AND DISCUSSION}

A one-way analysis of variance and Duncan's new multiple range test were conducted. Since Bartlett's test showed the existence of heteroscedasticity of the mean squares, original data (the single percentage values) were transformed according to the function arcsin $\sqrt{\mathrm{x}}$. The calculations were made on a HP9835A computer using the programs MSTEST, ANOva 1 and DunCAN written by one of us (Marchetti).

TABL. 1. - Results of effectiveness obtained by treating honey bee colonies with Folbex $V A$

\begin{tabular}{|c|c|c|c|c|c|c|c|c|}
\hline \multirow{2}{*}{$\begin{array}{l}\text { Hive } \\
\text { No. }\end{array}$} & \multicolumn{4}{|c|}{ Mites captured per treatment } & \multirow{2}{*}{ Total } & \multirow{2}{*}{$\begin{array}{l}\text { Left } \\
\text { Alive }\end{array}$} & \multirow{2}{*}{$\begin{array}{c}\text { Grand } \\
\text { Total }\end{array}$} & \multirow{2}{*}{$\begin{array}{c}\text { Eff. } \\
\%\end{array}$} \\
\hline & $1 \mathrm{st}$ & 2nd & $3 r d$ & $4 \mathrm{th}$ & & & & \\
\hline 1 & 609 & 197 & 308 & 179 & 1293 & 91 & 1384 & 93.4 \\
\hline 2 & 1590 & 412 & 76 & 38 & 2116 & 41 & 2157 & 98.1 \\
\hline 3 & 1535 & 350 & 206 & 102 & 2193 & 86 & 2279 & 96.2 \\
\hline 4 & 5573 & 629 & 205 & 123 & 6530 & 112 & 6642 & 98.3 \\
\hline 5 & 2718 & 651 & 195 & 115 & 3679 & 65 & 3744 & 98.3 \\
\hline 6 & 4425 & 946 & 961 & 284 & 6616 & 193 & 6809 & 97.2 \\
\hline 7 & 1841 & 627 & 932 & 216 & 3616 & 72 & 3688 & 98.0 \\
\hline 8 & 1272 & 457 & 131 & 491 & 2351 & 224 & 2575 & 91.3 \\
\hline 9 & 1351 & 744 & 403 & 167 & 2665 & 45 & 2710 & 98.3 \\
\hline 10 & 4676 & 2720 & 1173 & 618 & 9187 & 1021 & 10208 & 90.0 \\
\hline $\begin{array}{l}\text { Total } \\
\text { Col. }\end{array}$ & $\begin{array}{l}25590 \\
(60.6)\end{array}$ & $\begin{array}{c}7733 \\
(18.3)\end{array}$ & $\begin{array}{c}4590 \\
(10.9)\end{array}$ & $\begin{array}{l}2333 \\
(5.5)\end{array}$ & $\begin{array}{l}40246 \\
(95.4)\end{array}$ & $\begin{array}{l}1950 \\
(4.6)\end{array}$ & $\begin{array}{c}42196 \\
(100.0)\end{array}$ & \\
\hline
\end{tabular}


Tables 1, 2, 3 and 4 show the results obtained with each product. The results of Barlett's test indicated significant heteroscedasticity (chi-square $=17.8$, d.f. $=3, P=0.01$ ) and the existence of two mean squares, one definitely greater than the other; these two are relative to Thymol and Folbex VA, respectively (see also Tabl. 1 and 4).

TABL. 2 - Results of effectiveness obtained by treating honey bee colonies with Apiakaridim

\begin{tabular}{|c|c|c|c|c|c|c|c|c|}
\hline \multirow{2}{*}{$\begin{array}{l}\text { Hive } \\
\text { No. }\end{array}$} & \multicolumn{4}{|c|}{ Mites captured per treatment } & \multirow{2}{*}{ Total } & \multirow{2}{*}{$\begin{array}{l}\text { Left } \\
\text { Alive }\end{array}$} & \multirow{2}{*}{$\begin{array}{c}\text { Grand } \\
\text { Total }\end{array}$} & \multirow{2}{*}{$\begin{array}{c}\% \\
\text { Eff. }\end{array}$} \\
\hline & $1 \mathrm{st}$ & 2nd & $3 \mathrm{rd}$ & 4 th & & & & \\
\hline 11 & 2529 & 516 & 69 & 84 & 3198 & 14 & 3212 & 99.6 \\
\hline 12 & 838 & 1436 & 1207 & 220 & 3701 & 217 & 3918 & 94.5 \\
\hline 13 & 2575 & 2065 & 911 & 331 & 5882 & 42 & 5924 & 99.3 \\
\hline 14 & 829 & 1540 & 1348 & 270 & 3987 & 816 & 4803 & 83.0 \\
\hline 15 & 685 & 1004 & 1175 & 166 & 3030 & 598 & 3628 & 83.5 \\
\hline 16 & 2343 & 2935 & 2576 & 696 & 8550 & 619 & 9169 & 93.2 \\
\hline 17 & 732 & 1289 & 1226 & 235 & 3482 & 331 & 3813 & 91.3 \\
\hline 18 & 6166 & 2056 & 217 & 102 & 8541 & 104 & 8645 & 98.8 \\
\hline 19 & 203 & 243 & 908 & 81 & 1435 & 173 & 1608 & 89.2 \\
\hline 20 & 410 & 500 & 1335 & 139 & 2384 & 1602 & 3986 & 59.8 \\
\hline $\begin{array}{l}\text { Total } \\
\text { Col. }\end{array}$ & $\begin{array}{l}17310 \\
(35.5)\end{array}$ & $\begin{array}{l}13584 \\
(27.9)\end{array}$ & $\begin{array}{l}10972 \\
(22.5)\end{array}$ & $\begin{array}{l}2324 \\
(4.8)\end{array}$ & $\begin{array}{l}44190 \\
(90.7)\end{array}$ & $\begin{array}{l}4516 \\
(9.3)\end{array}$ & $\begin{array}{c}48706 \\
(100.0)\end{array}$ & \\
\hline
\end{tabular}

TABL. 3. - Results of effectiveness obtained by treating honey bee colonies with Taktic

\begin{tabular}{c|c|c|c|c}
\hline $\begin{array}{c}\text { Hive } \\
\text { No. }\end{array}$ & $\begin{array}{c}\text { Mites } \\
\text { Captured }\end{array}$ & $\begin{array}{c}\text { Left } \\
\text { Alive }\end{array}$ & $\begin{array}{c}\text { Grand } \\
\text { Total }\end{array}$ & $\begin{array}{c}\% \\
\text { Eff. }\end{array}$ \\
\cline { 2 - 4 } 21 & & & & \\
22 & 6369 & 315 & 6684 & 95.3 \\
23 & 4297 & 129 & 4426 & 97.1 \\
24 & 3600 & 75 & 3675 & 98.0 \\
25 & 5483 & 72 & 5555 & 98.7 \\
26 & 5776 & 1030 & 6806 & 84.9 \\
27 & 2613 & 379 & 2292 & 87.3 \\
28 & 4712 & 887 & 5599 & 84.2 \\
29 & 1031 & 98 & 1129 & 91.3 \\
30 & 3324 & 957 & 4281 & 77.6 \\
\hline & 1896 & 22 & 1918 & 98.9 \\
\hline Total & 39101 & & & \\
Col. & $(90.8)$ & 3964 & 43065 & \\
\hline \hline
\end{tabular}


TABL. 4. - Results of effectiveness obtained by treating honey bee colonies with Thymol crystals .

\begin{tabular}{|c|c|c|c|c|c|c|c|c|}
\hline \multirow{2}{*}{$\begin{array}{l}\text { Hive } \\
\text { No. }\end{array}$} & \multicolumn{4}{|c|}{ Mites captured per treatment } & \multirow{2}{*}{ Total } & \multirow{2}{*}{$\begin{array}{l}\text { Leit } \\
\text { Alive }\end{array}$} & \multirow{2}{*}{$\begin{array}{l}\text { Grand } \\
\text { Total }\end{array}$} & \multirow{2}{*}{$\begin{array}{c}\% \\
\text { Eff. }\end{array}$} \\
\hline & 1 st & 2nd & $3 \mathrm{rd}$ & 4th & & & & \\
\hline 31 & 1111 & 545 & 366 & 253 & 2275 & 17.4 & 2449 & 92.9 \\
\hline 32 & 618 & 385 & 178 & 215 & 1396 & 1327 & 2723 & 51.3 \\
\hline 33 & 715 & 720 & 714 & 420 & 2569 & 3869 & 6438 & 41.1 \\
\hline 34 & 549 & 336 & 236 & 118 & 1239 & 605 & 1844 & 67.2 \\
\hline 35 & 1312 & 1092 & 517 & 405 & 3326 & 341 & 4167 & 79.8 \\
\hline 36 & 184 & 267 & 171 & 87 & 709 & 325 & 1034 & 68.6 \\
\hline 37 & 983 & 645 & 272 & 261 & 2161 & 652 & 2813 & 76.8 \\
\hline 38 & 467 & 303 & 199 & 119 & 1088 & 639 & 1727 & 63.0 \\
\hline 39 & 2092 & 695 & 524 & 368 & 3679 & 2120 & 5799 & 63.4 \\
\hline 40 & 1498 & 609 & 500 & 250 & 2857 & 624 & 3481 & 82.1 \\
\hline $\begin{array}{l}\text { Total } \\
\text { Col. }\end{array}$ & $\begin{array}{c}9529 \\
(29.5)\end{array}$ & $\begin{array}{c}5597 \\
(17.3)\end{array}$ & $\begin{array}{c}3677 \\
(11.4)\end{array}$ & $\begin{array}{l}2496 \\
(7.7)\end{array}$ & $\begin{array}{l}21299 \\
(66.0)\end{array}$ & $\begin{array}{l}10996 \\
(34.0)\end{array}$ & $\begin{array}{c}32295 \\
(100.0)\end{array}$ & \\
\hline
\end{tabular}

One-way analysis of variance on arcsin transformed data showed a significant difference in effectiveness among the products $(F=12.9, \mathrm{P}=0.01)$. Duncan's multiple range test showed that the only product whose efficacy differs significantly from the remaining ones is Thymol $(P=0.01)$.

The numbers of mites fallen onto the winter inserts is reported in Tabl. 5, the one regarding the spring capture with Folbex VA in Tabl. 6.

The mite response-curves to the four products are represented in Figs 1, 2 and 3 .

The observations made during autumn 1983 showed that the acaricide products Folbex VA, Apiakaridim and Taktic gave significantly better control than did Thymol crystals. The average percentage of efficacy differed by $21-27 \%$.

It must be emphasized that Thymol crystals are still active after four days (Fig. 3); therefore, treatment could be applied at less frequent intervals. Since the substitution of the contents of a gauze bag causes an increase in mite fall, the number of treatments should be mantained at four. Simple calculations based on the observed rates of fall during the fifth and sixth day (Fig. 3) would suggest that an increase of the treatment period to 8 days (i.e. two days more at each treatment) could increase the effectiveness of the product up to $76 \%$. Another way to increase the efficacy of Thymol could be to add a new dose without removing the remains of the former one. However, possible overconcentration of the active ingredient in the hive atmosphere must be considered. 
Using $15 \mathrm{~g}$ of crystals per treatment and removing the previous gauze bag caused no noticeable damage to adult bees. When the compound was put near the brood, we observed the removal of many larvae and pupae from cells immediately adjacent to the gauze bag.

Although the air of the hive was permeated with Thymol for a long time and substitution of the gauze bag was made at midday, robbing was never observed.

The most important fact relative to the action of Thymol crystals concerns its great variability (Tabl. 4). This is difficult to explain in terms of our controlled conditions. Maybe the solution lies in the existence of interactions among colony strength and conditions of temperature and humidity in the hive. Perhaps the addition of a new gauze bag without the removal of the former one would not only increase the effectiveness of Thymol but also decrease the variability of results.

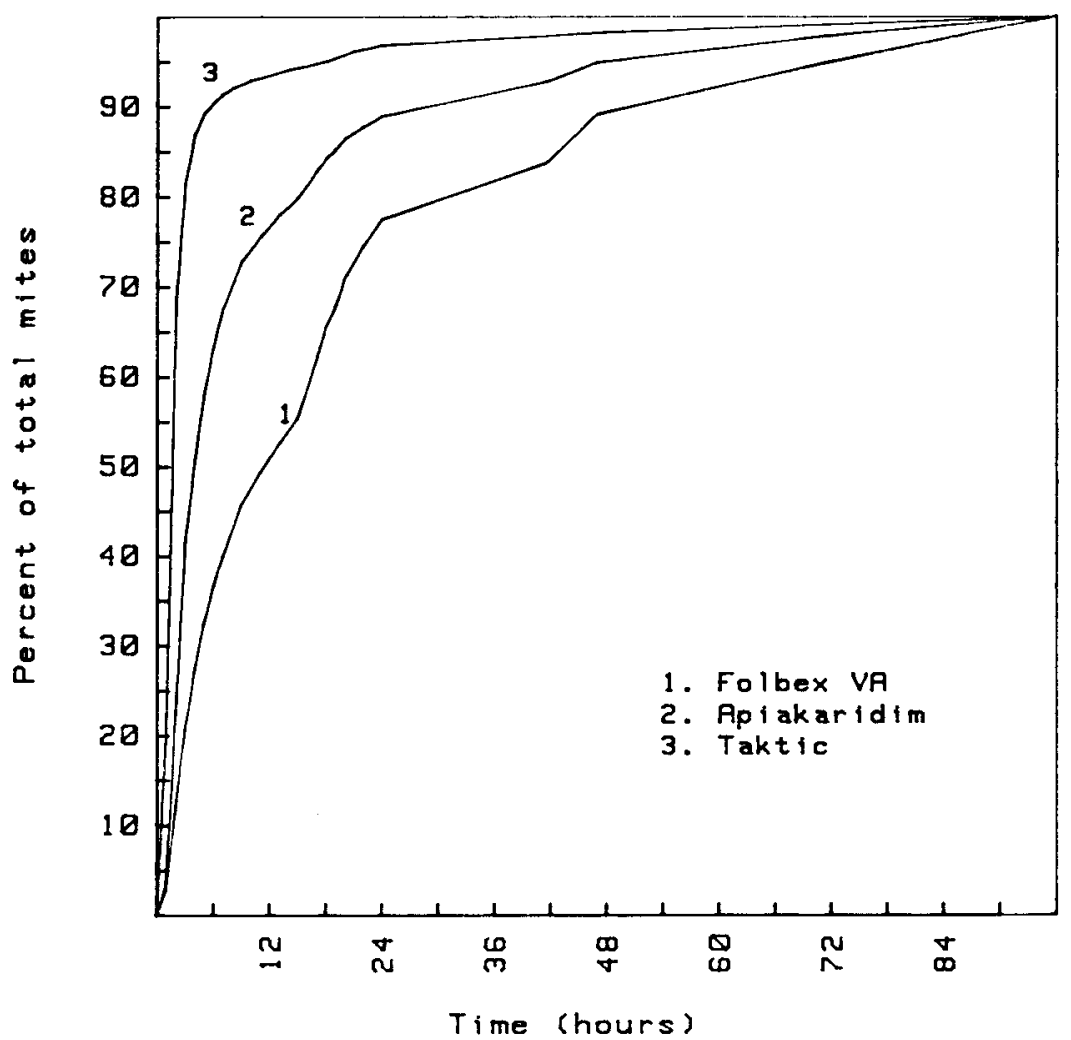

FiG. 1 - Folbex VA, Apiakaridim, Taktic: cumulative percentage of fallen mites over time 


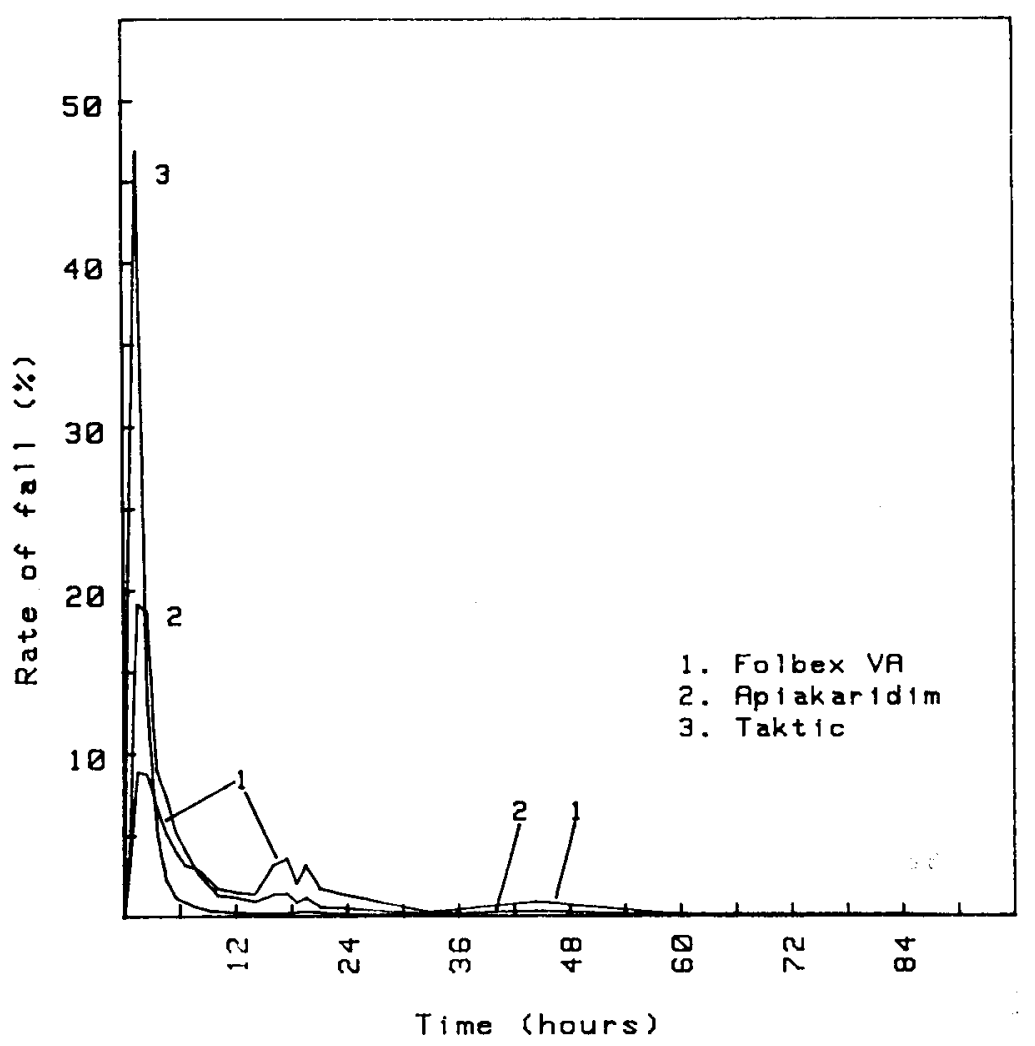

FIG. 2 - Folbex VA, Apiakaridim, Taktic : rate of the mite fall over time

The activity of Thymol was rather slow and it progressively decreased over time (Fig. 3). The effect of other products was much more evident in a short time but their action was limited to a range of some dozens of hours (Folbex VA) or even only some hours (Taktic) (Figs 1 and 2). The first treatment removed most mites from adult bees, successive treatments completed this action and affected newly emerged mites. This is particularly true for Folbex VA and Taktic which showed high efficacy at the first treatment (Tabl. 1 and 3). The number of fallen mites following the four fumigations with Apiakaridim are quite variable (Tab. 2). This may be due to different amounts of active ingredients in the two halves of the roll and uneven distribution of the acaricides inside each colony. This may be responsible for the abnormally low degree of control achieved in hive no. 20 (Tabl. 2). Problems concerning an equal distribution exist as well for Taktic aerosol treatment since the exit of the emulsion from the atomizer seems not to be perfectly regular (ACCORTI, unpublished). In addition, the effectiveness may be reduced by the presence of different amounts of brood. For want of the compensatory 
effect given by further treatments, the following are necessary : a) good calibration of the atomizer; b) strict observance of the times of the treatment; c) obtaining brood-free colonies (RITTER, 1984).

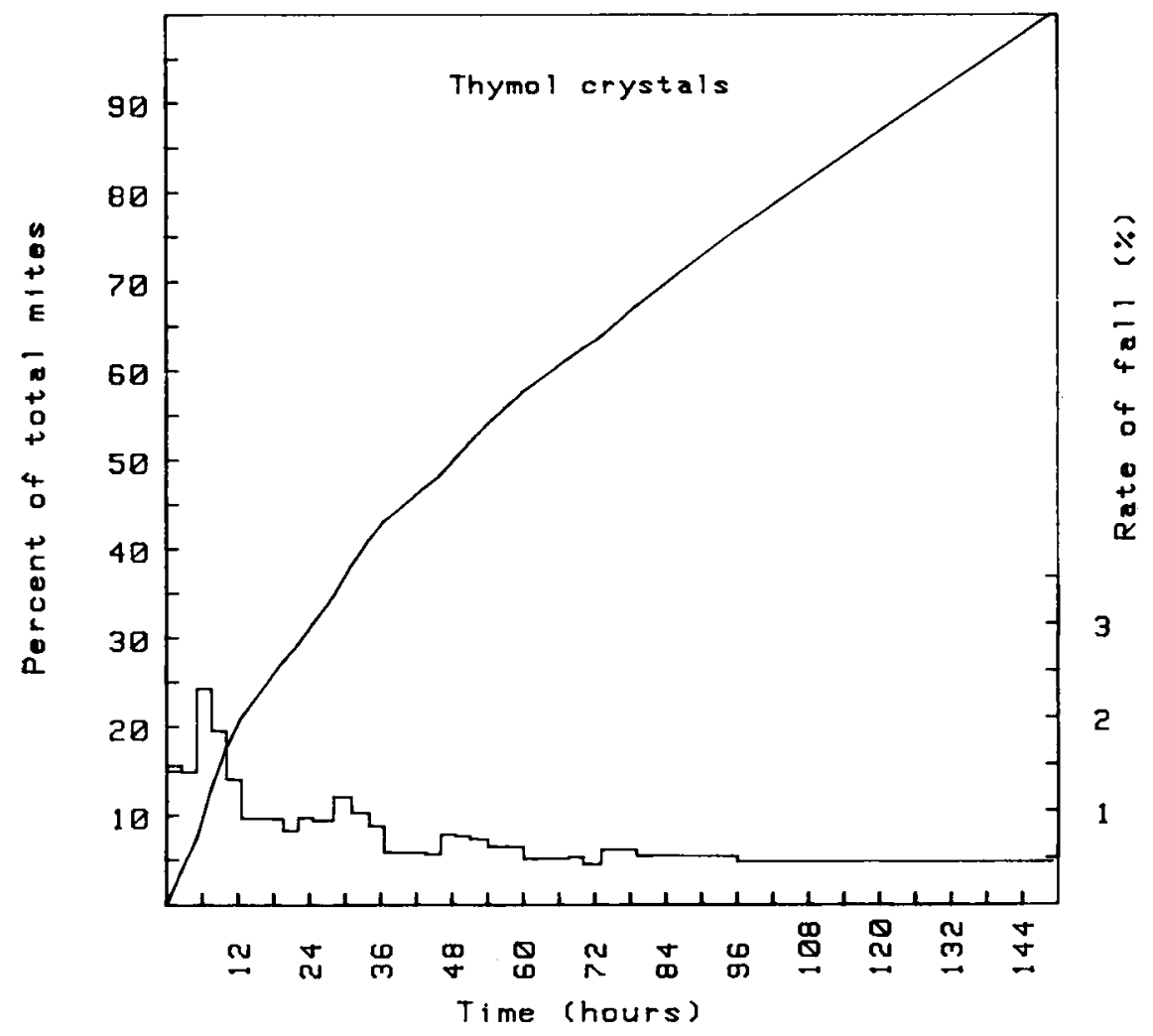

Fig. 3. - Thymol crystals :

cumulative percentage of fallen mites and rate of the mite fall over time

The product which showed the most consistent results was Folbex VA. The effective and consistent results agree with those achieved by ACCORTI in central Italy during the same period. No harmful effect was noticed on adult bees or brood. The same harmlessness characterized the action of Apiakaridim, while some doubt still exists for Taktic. In fact, we observed weakening of some treated colonies that in several cases had to be combined in the late winter with nuclei (the missing values in Tabs 5 and 6 are due to this). We were unable to assess whether the cause of weakening was due to the use of amitraz, the execution of a late treatment in the presence of a high degree of infestation, or both. An investigation of a quantitative nature should be carried out to explore this possibility. 
It is now opportune to ask how closely our $100 \%$ represents the whole. The values reported in Tabs 5 and 6 suggest that these two are quite similar; in fact, for a fair judgement of results, it must be pointed out that little amounts of brood were already present at the end of the year and no other periods of absence of brood (in the colonies for residue testing we noticed this condition by mid-November) could be detected during the colder winter months. In the apiary sited in the milder location brood rearing started a little sooner and continued at a greater rate.

TABL. 5. - Number of mites fallen onto the winter insert in each hive $(15 / 12 / 83-18 / 3 / 84)$

\begin{tabular}{|c|c|c|c|c|c|c|c|c|c|c|}
\hline Folbex VA ... & 12 & 9 & 1 & 4 & 9 & 17 & 4 & 3 & 5 & 1 \\
\hline Apiakaridim & 8 & 6 & 6 & 16 & 9 & 5 & 6 & 16 & 4 & 46 \\
\hline Taktic & - & 8 & 7 & 一 & - & - & 15 & - & 23 & - \\
\hline Thym. cryst. . ... & 35 & 5 & 16 & 34 & 66 & 31 & 30 & 29 & 10 & 28 \\
\hline
\end{tabular}

TABL. 6. - Number of mires captured in each hive using one strip of Folbex VA in the following spring $(18 / 3 / 84)$

\begin{tabular}{rr|r|r|r|r|r|r|r|r|r|r}
\hline \hline Folbex VA ..... & 8 & 10 & 6 & 5 & 6 & 8 & 10 & 5 & 8 & 10 \\
Apiakaridim $\ldots .$. & 10 & 20 & 13 & 12 & 15 & 18 & 14 & 9 & \multicolumn{2}{c}{$\begin{array}{c}\text { combined } \\
36\end{array}$} \\
Taktic ......... & - & 5 & 8 & - & - & - & 22 & - & 41 & - \\
\hline
\end{tabular}

During the spring and summer of 1984 , weather conditions were very bad so that normal development was disrupted. Swarming occurred often and led to generally low honey production. The colonies used to collect samples for residue testing behaved in the same way as those in which the trial for effectiveness was carried out. Also the colonies submitted to only four treatments of Thymol survived until October 1984. Therefore we are able to confirm that, in absence of secondary infections or any other disease, annual treatments with one of the tested products results in drastically limited damage due to Varroa. A rotation of Thymol crystals with another more effective acaricide, such as Folbex VA, will produce even better control. 
The manufacturers of Folbex VA recommend treatment in the absence of brood and with temperatures above $10{ }^{\circ} \mathrm{C}$. However, these conditions are not easily met in this region of Italy. Although there exist techniques for obtaining brood-free colonies (RITTER, 1984), not all of them are applicable in Italy. In particular, abundant feedings in order to fill all combs with food are difficult to achieve. Moreover, we noticed in our test hives that measures devoted to cooling the colonies are not sufficient to avoid the presence of brood at the time of treatment. Therefore, in our region it is more convenient to carry out the fumigations starting in mid-October or at least under conditions of « decreasing brood $»$. In that period a $4 \times 4$ pattern of treatment with Folbex VA is able to give an adequate level of control. In our opinion this pattern should be applied also to Apiakaridim, although the suggestions of the manufacturers are different.

Received for publication in October 1994. Accepted for publication in January 1985.

\section{ACKNOWLEDGEMENTS}

It is our duty and pleasure to thank the following persons: G. Mucchiut, M. Russian, L. Stabile who have kindly offered the use of their bee colonies; Dr W. RITTER of the Tierhygienisches Institut, Freiburg, West Germany for his suggestions given during the preparation of the trial; Dr L. KLuN and his colleagues of the Zveza cebelarskih drustev za Slovenijo, Ljubljana, Jugoslavia for the same reasons; Mr V.A. Cook of the ADAS National Beekeeping Unit, Stratford-Upon-Avon, England for correcting a great part of the English text; Prof. Z. Tercelu and Mrs M.V. Tommasi for their free services as Slavonian interpreters.

\section{RÉSUMÉ \\ ETUDE COMPARATIVE DE L'EFFICACITÉ DE QUELQUES TRAITEMENTS CONTRE VARROA JACOBSONI}

Les 4 produits commerciaux suivants, utilisés dans la lutte contre Varroa jacobsoni, ont été comparés : Folbex VA (bromopropylate, Ciba-Geigy), Apiakaridim (tedion + malathion, Dalmed), Taktic (amitraz, Fbc) et Thymol (cristaux, Janousek). Les expériences ont eu lieu dans la région de Friuli-Venezia Giulia sur 40 colonies (soit 10 colonies par produit) d'hybrides non contrôlées d'Apis mellifica carnica et A.m. ligustica.

\section{Méthodes}

Le traitement au Folbex $V A$ a commencé le 18 octobre. Les 4 traitements ont eu lieu à 4 jours d'intervalle au coucher du soleil, à une température extérieure supérieure à $10^{\circ} \mathrm{C}$, sur des ruches claustrées ne comportant pas de hausse vide. Lors du $2^{\circ}$ traitement, les langes ont été à plusieurs reprises intervertis, afin de tester sur l'acarien le facteur «temps». 
Un demi rouleau d'Apiakaridim a été utilisé pour traiter par roulement 15 colonies ( 5 colonies supplémentaires ont été traitées pour les recherches de résidus). Le traitement a été effectué 4 fois (aux mêmes dates que pour Folbex VA).

Pour Ie traitement avec Taktic, nous avons choisi a) la formulation aérosol produite par l'atomiseur Phagogène $\mathrm{S}$ Microdiffuseur, b) une concentration en amitraz de l'émulsion égale à $2 \mathrm{ml} / \mathrm{l}$, c) une durée de traitement d'environ 150 secondes par colonie, d) une température de $37^{\circ} \mathrm{C}$ à la sortie du nébuliscur. Nous n'avons traité qu'une fois, le 28 octobre. Les trous de vol étaient largement ouverts et les ruches possédaient une hausse vide.

Pour le Thymol, nous avons utilisé la substance pure $(99 \%)$. Les cristaux écrasés étaient placés dans de petits sacs de gaze, suspendus entre 2 rayons externes à l'intérieur de la ruche. Ia dose globale par ruche a été de $15 \mathrm{~g}$, administrée en 4 fois à 4 jours d'intervalle. Le trou de vol a été réduit à son ouverture hivernale. Le traitement a été commencé le 12 octobre.

Durant les traitements, sur les 4 lieux, on a enregistré les températures à laide d'un thermohygrographe. Afin de déterminer le nombre d'acariens restants, on a encagé les reines à la fin des expériences et traité 2 fois au Folbex VA (à un jour d'intervalle) après éclosion de tout le couvain. On a déterminé en outre la mortalité spontanée des acariens sur tout l'hiver et le 18 mars effectué un autre traitement avec un ticket de Folbex VA (sauf pour les colonies du groupe Thymol). Au printemps et en été 1984 on a suivi l'état des colonies choisies pour fournir des échantillons de miel et de cire en vue des recherches de résidus, et on l'a comparé à celui des colonies qui avaient subi tout le programme expérimental. Au cours de l'hiver on a noté la présence ou l'absence de couvain et de jeunes abeilles.

\section{Résultats et discussion}

Les tableaux 1, 2, 3 et 4 donnent les résultats pour chacun des produits testés. Le tcst de BartLeTt indique une hétéroscédasticité significative $\left(\chi^{2}=17,8 ;\right.$ d.f. $\left.=3 ; P=0,01\right)$ en raison de l'existence de 2 variances, l'une nettement plus grande que l'autre; elles sont respectivement relatives au Thymol et au Folbex VA.

Lanalyse de lia variance à 1 critère de classification sur des données ayant subi une transformation arcsin montre des différences significatives dans l'efficacité des divers produits ( $\mathrm{F}=12,9 ; \mathrm{P}=0.01)$. Le test de Duncan montre que le seul produit dont l'efficacité diffère des autres de manière significative est le Thymol $(P=0,01)$. Le tableau 5 donne le nombre d'acariens tombés sur les linges pendant l'hiver, le tableau 6 celui des acariens capturés au printemps avec Folbex VA. Les courbes de réponse de l'acarien aux 4 produits sont présentées en figures 1,2 et 3.

Le Folbex VA, l'Apiakaridim et le Taktic ont été significativement plus efficaces que le Thymol. La différence moyenne d'efficacité est de $21-27 \%$. Le Thymol ne s'évapore pas totalement en 4 jours, de sorte qu'il serait possible d'allonger l'intervalle entre 2 traitements. Une autre amélioration consisterait à administrer la nouvelle dose sans enlever les restes de la précédente. Dans ce cas, un préjudice au couvain serait possible; néanmoins il n'a pas été observé avec notre mode d'application. Lorsque, dans une expérience particulière, nous avons utilisé du Thymol à proximité du couvain, nous avons noté l'élimination de nombreuses larves et nymphes. Mais le problème le plus important avec le Thymol concerne sa grande variabilité d'action (Tabl. 4), qu'il est peut-être possible d'expliquer par la combinaison de plusieurs facteurs (force de la colonie, température, humidité à l'intérieur de la ruche). L'action du Thymol a été plutôt lente et s'est amoindrie avec le temps (Fig. 3), alors que celle du Folbex VA s'est mesurée en douzaines d'heures et celle de Taktic en heures (Fig. 1 et 2).

Des problèmes relatifs à la distribution régulière du produit sont apparus avec Apiakaridim. C'est Folbex VA qui a fait preuve de laction la plus constante et en même temps totalement dénuée de danger pour les abeilles et le couvain. On a pu établir la même innocuité pour Apiakaridim, alors que quelques doutes subsistent encore pour Taktic. Certaines colonies traitées ont été affaiblies, si bien qu'elles ont dû réduire leur ponte (cf. les valeurs manquantes dans les 
tableaux 5 et 6), mais il n'est pas certain que cet affaiblissement soit à rapporter à l'amitraz; la date tardive du traitement ou le degré d'infestation élevé peuvent en avoir été la cause.

Au printemps et en été 1984, tous les groupes de ruches présentaient le même comportement. On peut constater que, par administration annuelle de l'un de ces 4 produits et en l'absence d'autres maladies, les dégâts causés par Varroa peuvent être limités de façon très nette. Pour le Thymol il semble nécessaire de l'utiliser alternativement avec un acaricide plus puissant. En Italie il est avantageux d'effectuer le traitement au stade de «couvain décroissant» (à la fin de l'automne). Avec 4 traitements à cette époque, il est possible d'obtenir de bons résultats, tels ceux exposés ici.

\title{
ZUSAMMENFASSUNG
}

\author{
VERGLEICH DES WIRKUNGSGRADES EINIGER ZUR BEKAMPFUNG \\ VON VARROA JACOBSONI OUD. EINGESETZTER MITTEL
}

Die vier folgenden Mittel wurden getestet : Folbex VA (Bromopropylat, Ciba-Geigy), Apiakaridim (Tedion + Malathion, Dalmed), Taktic (Amitraz, Fbc) und Thymol (Kristalle, Janousek). Jedes Mittel wurde viermal angewandt. Die Versuche wurden in der Region Friuli-Venezia Giulia an 40 Völkern (d.h. an 10 Völkern je Mittel) einer unkontrollierten Kreuzung von Apis mellifera carnica und A.m. ligustica durchgeführt.

\section{Methoden}

Die Behandlung mit Folbex VA begann am 18. Oktober. Die vier Behandlungen wurden mit vier Tagen Abstand bei Sonnenuntergang und bei Temperaturen über $10^{\circ} \mathrm{C}$ durchgeführt. Dabei waren die Fluglöcher geschlossen, es wurde kein leerer Honigraum gegeben. Bei der zweiten Behandlung wurden die Einlagen in rascher Folge mehrmals gewechselt, um die zeitabhängige Wirkung auf die Milbe zu prüfen.

Bei Apiakaridim wurde bei den vier Behandlungen (zu denselben Terninen wie Folbex AV) an die 15 Versuchsvölker (5 Völker wurden zusätzlich für Rückstandsuntersuchungen behandelt) im Rotationsverfahren mit einem halben Streifen des Präparates behandelt.

Für den Versuch mit Taktic, haben wir gewählt : a) Vernebelung des Präparates mit dem «Phagogène S Microdiffuseur»; b) Amitraz-Konzentration der Emulsion : $2 \mathrm{ml} / \mathrm{l} ; \mathrm{c}) \mathrm{Be}-$ handlungszeit ca $150 \mathrm{sec}$ per Volk; d) Temperatur an der Öffnung des Gerätes $37^{\circ} \mathrm{C}$. Wir haben nur ein einziges Mal, am 28. Oktober, behandelt. Die Fluglöcher waren weit geöffnet und es wurde ein leerer Aufsatz gegeben.

Bei Thymol haben wir die reine Substanz $(99 \%)$ benutzt. Die Kristalle wurde im Mörser zerrieben und in kleinen Gazesäckchen zwischen zwei äußeren Waben ins Volk gehängt. Die Dosis per Volk betrug $15 \mathrm{~g}$, verabreicht in vier Einzeldosen in vier Tagen Abstand. Das Flugloch war auf Wintergröße verengt. Die Behandlung begann am 12. Oktober.

Während der Behandlungen wurden die Temperaturen auf allen Ständen mit Thermohygrographen kontrolliert. Um die Zahl der überlebenden Milben zu bestimmen, wurden nach Beendigung der Versuche die Königinnen gekäfigt, um nach Ausschlüpfen der letzten Brut zwei Mal mit Folbex VA (mit eintägigem Abstand) zu behandeln. Außerdem haben wir wintersüber den Spontanabfall der Milben bestimmt und am 18. März 1984 noch eine Behandlung mit einem Streifen Folbex VA durchgeführt (abgesehen von den Völkern der Thymol-Gruppe). Im Frühjahr und. Sommer 1984 haben wir den Zustand der Völker, die zur Entnahme von Honig- und Wachsproben für Rückstandsuntersuchungen bestimmt waren, verfolgt und ihn mit dem der Völker verglichen, an denen das ganze Versuchsprogramm durchgeführt worden war. Während des Winters wurde das Vorhandensein oder Fehlen von Brut und Jungbienen beobachtet. 


\section{Resultate und Diskussion}

Die Tabellen $\mathrm{Nr} 1,2,3$ und 4 enthalten die Resultate für jedes der getesteten Produkte. Nach dem Bartlettschen Test ist die Heteroskedastizität signifikant $\left(\chi^{2}=17,8 ;\right.$ d.f. $\left.=3 ; \mathrm{P}=0,01\right)$, da zwei Varianzen bestehen, die voneinander unterschiedlich sind (Thymol und Folbex VA).

Die Varianzanalyse mit einem einzigen Klassifikations-Kriterium der Daten, die einer arksinUmwandlung unterworfen wurden, zeigt signifikante Unterschiede in der Wirksamkeit der verschiedenen Produkte $(F:=12,9 ; P=0,01)$. Der Duncansche Test zeigt, dass Thymol das einzige Produkt ist, dessen Wirksamkeit von derjenigen der anderen Produkte signifikant verschieden ist $(\mathbf{P}=0,01)$. Die Tabelle 5 zeigt die Anzahl der während des Winters auf die Einlagen gefallenen Milben und die Tabelle 6 die Anzahl der im Frühling mit Folbex VA gefangenen Miłben. Die Wirkungskurven auf die Milben von den 4 Produkten werden in den Abbildungen 1, 2 und 3 dargestellt.

Folbex VA, Apiakaridim und Taktic sind bedeutend wirksamer als Thymol. Der mittlere Unterschied beträgt in der Wirksamkeit 21-27\%. Während des vier Tage Intervall verdunsiet jedoch das Thymol nicht völlig, so daß dieser verlängert werden könnte. Eine andere Möglichkeit wäre, die nee Dosis zu geben, ohne die vorherige zu entfernen. Dabei besteht aber die Möglichkeit einer Schädigung der Brut, die bei unserer Anwendungsform nicht zu beobachten war. Als wir in einem gesonderten Versuch Thymol in die Nähe von Brut brachten, wurden Larven und Puppen entfernt.

Das größte Problem bei Thymol bildet aber die Unterschiedlichkeit der Wirkung (Tab. 4), die vielleicht durch ein Zusammenspiel mehrerer Faktoren (Volksstärke, Temperatur und Feuchte im Volk) erklärt werden können. Die Wirkung von Thymol erfolgt ziemlich langsam, mit allmählicher Abnahme (Abb. 3), während sich die Wirkung von Folbex VA in Dutzenden von Stunden und diejenige von Taktic sich sogar in Stunden messen läßt (Abb. 1 u. 2).

Bei Apiakaridim ergaben sich Probleme mit der gleichmäßigen Verteilung. Die höchste Konstanz der Wirkung war bei Folbex VA festzustellen, das sich zudem als völlig harmlos für Bienen und Brut erwies. Dieselbe Harmlosigkeit konnten wir für Apiakaridim feststellen, während diesbezüglich für Taktic noch einige Zweifel bestehen : Die behandelten Völker waren z.T. geschwächt, so daß sie mit Ablegern vereinigt werden mußten (siehe die fehlenden Werte in Tab. $5 \mathrm{u}$. 6). Es ist aber nicht gesichert, ob diese Schwächung dem Amitraz zuzuschreiben ist; Ursache könnte auch der späte Behandlungstermin oder der starke Befallsgrad sein.

Im Frühjahr und Sommer 1984 verhielten sich alle Versuchsgruppen ähnlich. Es kann festgestellt werden, daß durch die jährliche Anwendung eines dieser vier Mittel bei Abwesenheit anderer Erkrankungen Varroa-bedingte Schäden entscheidend begrerazt werden können. Bei Thymol wird es wahrscheinlich nötig sein, es abwechselnd mit einem Akarazid von stärkerer Wirkung anzuwenden. Für Italien ist es vorteilhaft, die Behandlung im Stadium der «abnehmenden Brut» (im Spätherbst) durchzuführen. Bei viermaliger Behandlung um diese Zeit können ähnlich gute Ergebnisse erzielt werden, wie sie hier berichtet werden.

\section{REFERENCES}

Alpatov V.V., Lange A.B., Natskit K.B., Tats V.M., 1977. - Work on the testing and application of treatments against Varroa. In : Varroa infestation of honey bees (edited by Alpatov V.V. and 6 others). Moscow, USSR, Izdatel'Stvo Nauka, 19-23 (in Apic. Abstr, 1979, 30, p. 211).

Arzone A., Vidano C., 1980. - Esame dell'azione sull'ape di isofenfos, amitraz e benomyl in laboratorio, Atti «Giornate fitopatologiche 1980», 1, 61-68. 
Cavalloro R., ed. 1983. - Discussions, conclusions and recommendations. In : Varroa jacobsoni Oud. affecting honey bees : present status and needs. Proceedings of a Meeting of the EC Experts' Group/Wageningen 1983, 91-96.

Chamoux H.M.L., 1977. - La varroase, une nouvelle et dangereuse parasitose des abeilles (Varroa jacobsoni Oudemans, 1904). Thèse pour le Doctorat Vétérinaire, Ecole Nationale Vétérinaire d'Alfort, France (in Apic. Abstr., 1978, 29, p. 265).

Cläerr G., 1983. - Prospettive per i metodi di lotta biologica alla varroasi. Atti Conv. Inter dell'Apicoltura, Lazise, 78-87.

De Jong D., Morse R.A., Eickwort G.C., 1982. - Mite pest of honeybees. Annu. Rev. Entomol., 27, 229-252.

Gnädinger F., 1979. - Prévention de l'introduction de la varroase dans les pays non infestés. In : Prophylaxie et lutte contre la varroase, Séminaire OIE/APIMONDIA. Bucarest, 98-102.

Grobov O.F., 1977. - La varroase des abeilles. In : La varroase maladie de l'abeille mellifère. Editions Apimondia, Bucarest, 52-98.

Maul V., Petersen N., Wissen W., 1980. - Feldversuche zur klinischen Erprobung von Kelthane und Brompropylat, Allg. disch. Imkerztg., 14 (5), 149-150.

Poltev V.I., 1978. - Varroa disease of honeybees, Veterinariya, 3, 73-75 (in Apic. Abstr., 1980, 31, p. 109).

MEL'NIK V.N., 1979. - Effectiveness of some ways of attacking varroa disease in honeybees, Pchelovodstvo, (1) 12-14 (in Apic. Abst., 1980, 31, p. 190).

RakHmatulin R.G., 1978 a. - Effectiveness of preparations for treatment of Varroa jacobsoni, Pchelovodstvo, (2) 12-13 (in Apic. Abstr., 1979, 30, p. 209).

RakHmatulin R.G., 1978 b. - Trials of preparations for control of Varroa infestation of honeybees, Veterinariya, 3, 71-73 (in Apic. Abstr., 31, 189).

RitTer W., 1981. - Varroatosis, a new disease of the bee Apis mellifera. Animal Research and Development, 14, 17-35.

RITTER W., 1984. - Neuester Stand der diagnostischen und therapeutischen Maßnahmen zur Bekämpfung der Varroatose. Tierärztliche Umschau, 39 (2), 122-127.

Ritter W., De Jong D., 1984. - Reproduction of Varroa jacobsoni Oud. in Europe, the Middle East and tropical South America. J. Appl. Entomol., 98 (1), 55-57.

Ritter W., Perschil F., 1983. - Determination of the effect of Folbex VA (isopropyl - 4,4' Dibromobenzilate) on Varroa mites and of the tolerance of bees, Animal Research and Development, 17, 28-40.

Ritter W., Delaitre N., Ifantidis N., 1983 a. - Le risque de réinvasion par Varroa jacobsoni après l'administration de Folbex VA. Résumés du XXIX' Congrès International d'Apiculture, APIMONDIA, Budapest, p. 176.

Ritter W., Perschil F., Vom Hövel R., 1983 b. - La lutte contre la varroase par l'élimination continuelle du couvain operculé de faux bourdons. Résumés du XXIX' Congrès international d'Apiculture, APIMONDIA, Budapest, p. 176.

Ruttaner F, Koeniger N., 1979. - Essais d'élimination des acariens Varroa par des méthodes biologiques. Le XXVII ${ }^{\mathrm{e}}$ Congrès International d'Apiculture, APIMONDIA, Athènes, 401-404.

Ruttner F., Koeniger N., 1980 a. - Eine biologische Methode zur Eliminierung der VarroaMilben aus Bienenvölkern. Allg. disch. Imkerztg., 14 (5), 159-160.

Ruttner F., Koeniger N., Ritter W., 1980 b. - Brutstop und Brutentnahme. In : Die Varroatose der Honigbiene, Allg. dtsch. Imkerztg., 14 (1), 11-12.

SANTAS L.A., 1983. - Varroa disease in Greece and its control with Malathion. In : Varroa jacobsoni Oud. affecting honeybees : present status and needs. Proceedings of a Meeting of the EC Experts' Group/Wageningen 1983, 73-76.

Smirnov A.M., 1978. - Progrès actuels de la science en Union Soviétique dans l'étude de l'éthiologie, de la pathogénie, de l'épizootologie, du diagnostic et de la lutte contre la varroase des abeilles, Apiacta, 13 (4), 149-162. 